Łukasz Chyla*

ORCID: 0000-0001-7353-8125

Uniwersytet Jagielloński

DOI: $10.19195 / 1733-5779.24 .6$

\title{
Latest remarks on the democracy and rule of law in CEE countries
}

Słowa kluczowe: państwo prawa, Europa Środkowo-Wschodnia, demokracja, konstytucjonalizm

Keywords: rule of law, Central Eastern Europe, democracy, constitutionalism

\begin{abstract}
Recently, most of the Central and Eastern European (CEE) countries are going through a very serious crisis of rule of law and constitutional democracy - especially comparing to the EU "accession period". The apparently successful transition process, adopting the constitutional democracy and the rule of law in CEE countries is now facing serious challenges. Despite the illusive ideological solidarity, common values and increasing harmonization of law within the European Community, a contrast between the image and the reality has become visible. It turned out that apparently democratically mature new members of the European Community are, in reality, functioning in the shadows of informal networks, political systems and local correlations while rule-of-law institutions are often too weak or underdeveloped and continuously fail to limit the abuse of uncontrolled state power. Interestingly, early signs of such shallow Europeanisation of the CEE political and legal systems has been for long marginalized by European Community. The cause of the current state is of deeply structural character, and constitutes mostly a proof of failure of defectively carried out process of transformation. The aim of the article is to present some comparative perspective on the subject and discuss the potential reasons of backsliding of CEE legal and political systems.
\end{abstract}

\section{Aktualne uwagi na temat demokracji i rządów prawa w krajach Europy Środkowo-Wschodniej}

W ostatnim czasie większość krajów Europy Środkowej i Wschodniej przechodzi bardzo poważny kryzys rządów prawa i demokracji konstytucyjnej, szczególnie w porównaniu z tzw. okresem akcesyjnym UE. Udany proces transformacji, przyjęcie demokracji konstytucyjnej i rządów prawa w krajach Europy Środkowo-Wschodniej stoi obecnie przed poważnymi wyzwaniami. Pomimo iluzorycznej ideologicznej solidarności, wspólnych wartości i rosnącej harmonizacji prawa we Wspólnocie Europejskiej, widoczny staje się kontrast między tym wyidealizowanym

* Opiekun naukowy (Scientific Tutor) — Andrzej Szumański 
obrazem a rzeczywistością. Okazało się, że pozornie dojrzali demokratycznie nowi członkowie Wspólnoty Europejskiej funkcjonują w rzeczywistości w cieniu nieformalnej sieci powiązań, podczas gdy instytucje rządów prawa są często zbyt słabe lub słabo rozwinięte i ciągle nie udaje im się ograniczyć nadużycia niekontrolowanej władzy państwowej. Co ciekawe, wczesne oznaki tak płytkiej europeizacji systemów politycznych i prawnych w Europie Środkowo-Wschodniej były długo marginalizowane przez Wspólnotę Europejską. Przyczyna obecnego stanu ma głęboki charakter strukturalny i stanowi głównie dowód niepowodzenia błędnie przeprowadzonego procesu transformacji. Celem artykułu jest przedstawienie pewnej perspektywy porównawczej na ten temat i omówienie potencjalnych przyczyn „odwrotu” prawnego i politycznego systemów CEE.

\section{Introduction}

Pursuant to the actual report Nations in Transit 2018 ${ }^{1}$, published by Freedom House organization, the year of 2018 led to the biggest decrease in a point-measured quality of democracy and the rule of law throughout the history of the rating, lasting 23 years. The problem applies to the majority of 29 examined countries, which have undergone the transformation process in the last decades. Perceivable and gradually aggravating democracy and law deficit is noted in Balkan, Eurasian and Central and Eastern European countries (CEE). The latter, however, concerns the most, since in the last 10 years the regress of constitutionalism has been noted to the greatest extent due to antidemocratic trends, even though most of representative countries of this group are actually full members of the European Union. It should also be pointed out that the phenomenon takes place with the substantial approval of societies in central and eastern European countries (for example in Poland and Hungary), which suggests the universality of crisis of values assigned to constitutionalism and decrease of democratic identity in all region. In the last decade those countries distanced themselves from value system well-known in the so-called "Old Europe", which is a presentation of acts assigned more to the "buffer zone" between the West and the East of Europe. It is enough to mention the last tendencies in respective central and eastern European countries, including but not limited to:

- turmoil surrounding the Constitutional Tribunal and continuing imbalance of power, through dependence of justice system and prosecution on legislative and executive in Poland ${ }^{2}$;

— nondemocratic and threatening political pluralism (however, enjoying a great popularity amongst the majority of society) Hungarian constitution amendments by the Fidesz party led by Victor Orban ${ }^{3}$;

- attempted usurpation of justice system, the dependence of prosecution on executive and efforts in order to decriminalize corruption, taken by the informal

1 Freedom House, Nations in Transit 2018: Confronting Illiberalism (2018), https://freedomhouse.org/report/nations-transit/nations-transit-2018 (access: 20.04.2018).

2 https://freedomhouse.org/report/nations-transit/2018/Poland (access: 20.04.2018).

3 J. Müller, "Defending democracy within the EU", J. Democracy 24, 2013, issue 2, pp. 138140, https://freedomhouse.org/report/nations-transit/2018/hungary (access: 20.04.2018). 
leader Liviu Dragnea, which led to the massive social protests in Romania, which are considered as the biggest protests on a European scale since the Berlin Wall fall ${ }^{4}$;

- spreading corruption in Bulgaria and the permanent inability to rule out the regime of the CVM ("controlling and verifying") temporary mechanism, which constitutes a form of EU-level supervision of the judiciary and public administration of this country ${ }^{5}$;

- deep structural crisis in Slovenia (beginning from 2010), enhanced by corruption and actual capturing of the state structure by the narrow postcommunist interest groups ${ }^{6}$.

Therefore, despite the illusive ideological solidarity, common values and increasing harmonization of law within the European Community, a contrast between the image and the reality has become visible. It turned out that apparently democratically mature and following the principle of legalism countries (in its European scale) are, in reality, functioning in the shadows of informal networks, political systems and local correlations ${ }^{7}$. The various hybrid and mutated forms of quasi-democracy, differing from the constitutional liberal democracy in its classic western scale, are becoming more and more visible. For the purpose of an accurate evaluation of range of the mentioned phenomenon, it is worth consulting and taking into deeper consideration the detailed results of renowned Nations in Transit reports, deriving from analysis lasting for several years.

\section{Analysis of the phenomenon in selected countries}

A long-term analysis of Nations in Transit suggests the decrease in state of democracy and rule of law in countries of Central-Eastern Europe. The growing crisis of constitutional values applies to almost all parts of the region, especially if compared to the results from the "around-accession" period, when young and aspiring democracies were successfully undergoing the procedure of admission to the group of European Union countries, are taken as a reference point (Graph no 1).

Pursuant to the report methodology, on the basis of the partial results evaluated by experts in 7 particular categories (democracy of governing on the central and municipal level, the course of electoral process, medias independence, civil

${ }^{4}$ https://freedomhouse.org/report/nations-transit/2018/romania (access: 20.04.2018).

5 V.I. Ganev, "Post-accession hooliganism: Democratic governance in Bulgaria and Romania after 2007", "E. Eur. Pol. \& Societies \& Cultures" 27, 2013, issue 1.

${ }^{6}$ B. Bugarič, „A crisis of constitutional democracy in post-Communist Europe: 'Lands in-between' democracy and authoritarianism, International Journal of Constitutional Law 13, January 2015, issue 1, pp. 219-245, https://doi.org/10.1093/icon/mov010 (access: 20.04.2018); P. Guasti, B. Dobovšek, B. Ažman, Deficiencies in the rule of law in Slovenia in the context of Central and Eastern Europe, Varstvoslovje. J. Crim. Justice \& Security 14, 2013, issue 2.

7 J. Rupnik, J. Zielonka, ,Introduction: The state of democracy 20 years on: Domestic and external factors", E. Eur. Pol. \& Societies \& Cultures 27, 2013, issue 1. 
Central European Countries' Democracy Scores Since Nations in Transit 2005

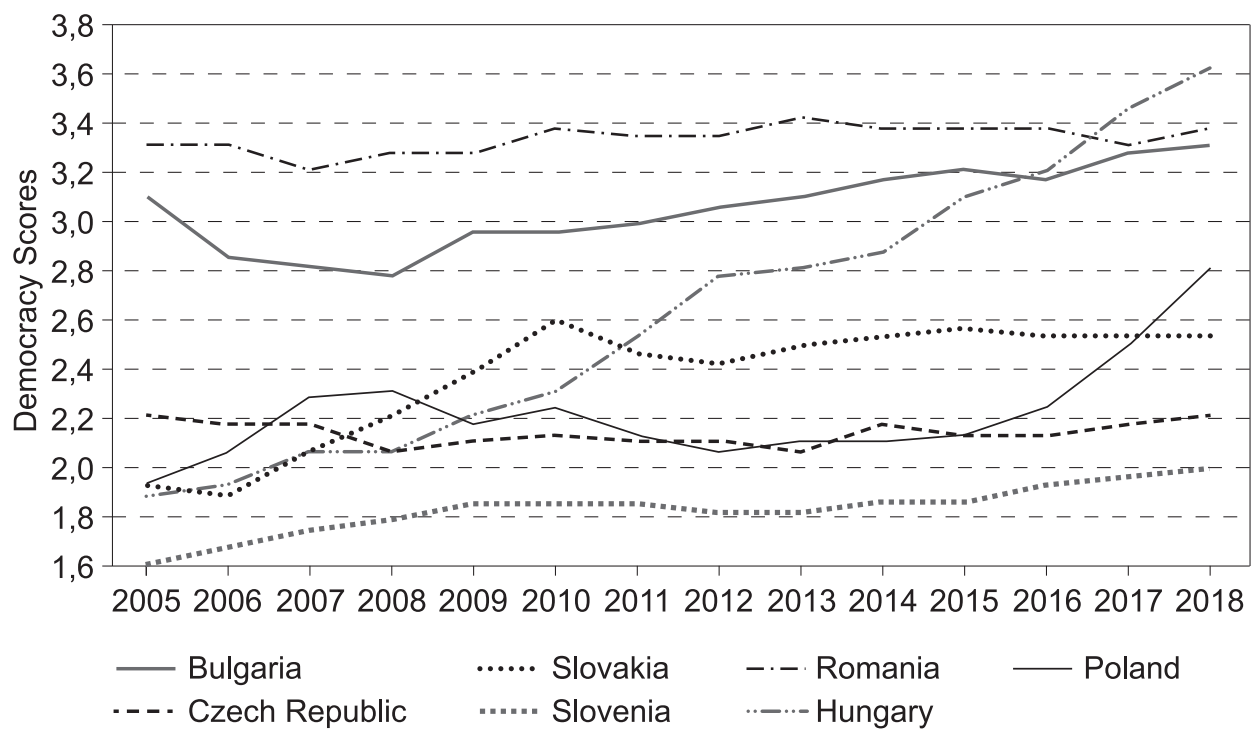

Graph 1. Results of selected Central-Eastern Europe countries in the category "democracy" (2005-2018)

Source: Freedom House, Nations in Transit 2018: Confronting Illiberalism (2018), available on: https:// freedomhouse.org/report/nations-transit/nations-transit-2018 (access: 20.04.2018).

society, judicial framework and independence, corruption score), each country obtains a resultant note, on a scale from 1 to 7 , in a general "democracy" category, where 1 means ideal liberal democracy, and 7 means closed authoritative system. Subsequently, countries are ranked as one of five systemizing terms: "consolidated

Table 1. Point results of selected Central-Eastern Europe countries in categories "Democracy", "Judicial Framework and Independence Score" and "Corruption Score"(2005-2018)

\begin{tabular}{|l|c|c|c|c|c|c|}
\cline { 2 - 7 } & \multicolumn{2}{c|}{ Democracy Score } & \multicolumn{2}{c|}{$\begin{array}{c}\text { Judicial Framework and } \\
\text { Independence Score }\end{array}$} & \multicolumn{2}{c|}{ Corruption Score } \\
\cline { 2 - 7 } & $\begin{array}{c}\text { Accession } \\
\text { Period }\end{array}$ & 2018 & $\begin{array}{c}\text { Accession } \\
\text { Period }\end{array}$ & 2018 & $\begin{array}{c}\text { Accession } \\
\text { Period }\end{array}$ & 2018 \\
\hline Bulgaria & 2.86 & 3.29 & 2.75 & 3.50 & 3.50 & 4.25 \\
\hline Czech Rep. & 2,14 & 2.29 & 2.00 & 1.75 & 3.25 & 3.50 \\
\hline Hungary & 1.96 & 3.71 & 1.75 & 3.0 & 2.75 & 4.75 \\
\hline Poland & 1.75 & 2.89 & 1.50 & 3.50 & 2.50 & 3.50 \\
\hline Romania & 3.29 & 3.46 & 3.75 & 3.75 & 4.00 & 3.75 \\
\hline Slovakia & 1.96 & 2.61 & 2.00 & 2.75 & 3.00 & 3.75 \\
\hline Slovenia & 1.68 & 2.07 & 2.13 & 2.0 & 2.00 & 2.75 \\
\hline
\end{tabular}

Source: Freedom House, Nations in Transit 2018... 
democracy" (from 1.0 to 2.99 points on a scale), "partially consolidated democracy" (from 3.0 to 3.99), "hybrid regime" (from 4 to 4.99), "partially consolidated authoritative regime" (from 5.0 to 5.99) and "consolidated authoritative regime" (from 6.0 to 7.0 points on a scale).

The conclusions about the ongoing regress of the democracy refers to almost each of the selected countries (Table no 1). However not longer than a decade ago Bulgaria and Hungary were qualified as "consolidated democracies", nowadays both countries are classified as "partially consolidated democracies", but Hungary is approaching fast the category of "hybrid regime" $(+1.75$, which constituted the biggest regress on a general scale). Also Poland, considered in the past as a role model of successful system transformation, nowadays it almost falls into category of "partially consolidated democracy" $(+1.14$, which is the second biggest regress on a general scale). Currently, the status of stable democracy can be attributed only to Czech Republic $(+0.15)$ and Slovenia $(+0.39)$. Romania, nearby reaching "consolidated democracy" level while accessing the European Union in 2007, regressed in the score of rule of law and legalism $(+0.17)$.

Interestingly, the alarming results in the "Democracy" category represent only the tip of the iceberg. The reason for this is that this broad category is only a resultant of 7 other partial categories. The notably worse situation is visible in respect of democratic country base on rule of law evaluation. Amongst the Nations in Transit reports, the categories which reflect best this state are "judicial framework and independence" and "corruption score". The first of those categories determines the power of real civil rights guarantees. The second is of a particular importance from the perspective of evaluating the effectiveness of the legal system against many interest groups intending to seize the country - corruption is understood also as a general phenomenon characterized by inequality of citizens before the law, under the pressure of the particular interest groups.

In accordance with Nations in Transit 2018 Report, the evaluation of judicial framework and independence in particular Central-Eastern Europe countries presents a significant backward step in implementation of values known in Western democracies into domestic legal systems. In this category, as "consolidated" democracies can be qualified only Czech Republic, Slovenia and Slovakia. The other countries are clustered around the middle of the scale applicable to "partially consolidated democracies". Special example should be made of Poland $(+2.00$, the biggest regress in this category) and Hungary $(+1.75$, the second biggest regress in this category), where a number of reforms have undermined the constitutional rule of a tri-partite diversion of power and a full independence of judicial system.

What concerns even more, is the corruption score. In this field none of the countries - except for Slovenia - can be proudly claimed to be a consolidated democracy. What is more, a title of consolidated democracy applies only to Czech Republic $(+0.25)$, Poland $(+1.0$, which constitutes the second biggest regress, following Hungary), Romania (-0.25 — the only improvement in this category) and 
Slovakia $(+0.75)$. Bulgaria $(+0.75)$ and Hungary $(+2.0$, which is the biggest regress) fall into the category of "hybrid regimes".

It should be also pointed that on the basis of report authors' opinion there appeared a sudden degeneration of democratic governing in case of Poland and Hungary, consecutively +2.0 and +2.5 in comparison with the "around-accession" period.

The presented results are surprising, in particular when taken into consideration that in the period from 2004 to 2010 the majority of Central-Eastern Europe countries have been praised for an exceptional increase in rule of law and effective implementation of Western-like liberal democracy conception. After their accession to the European Union it seemed that postcommunist countries were on their best way to "return to Europe", and a process of full transformation and conversion to constitutional and democratic states based on rule of law was just a question of time ${ }^{8}$. Where things went wrong, though? What is the source of the sudden antidemocratic "decrease and backward step", which is the cause of systematic dismantling of liberal-democratic achievements of the previous decade? ${ }^{9}$

In my opinion, the statements that antidemocratic decrease in Central-Eastern European countries is of a sudden nature, are - at least partially — exaggerated. The cause of the current state are of deeply structural character, and the problem has not been noticed (or maybe - permanently marginalized) by Western Europe countries. Being probably in part a postponed effect of financial crisis (2008-2011), the current regress constitutes mostly a proof of failure of defectively carried out process of transformation ${ }^{10}$. Superficiality of "Europeanisation" of changes in fields of law and social-economic issues was not a remedy for the growing tensions and social expectances, but, what is more, it even escalated them. This matter is, moreover, much more complex - in the next chapter I will try to present a couple of theories on the reasons, which could lead to the current state.

\section{Potential causes of democracy regress in Central-Eastern European countries}

Firstly, many commentators notice that due to traumatic historic events, all the region is characterized by a weak rule of law tradition regarding issues such as human rights, protection of minorities rights and, in general, a connection between law and morality ${ }^{11}$. Above all, there is a striking resemblance between legal

8 Ibid., s. 21; B. Bugarič, op. cit., p. 221.

9 B. Greskovits, „The hollowing and backsliding of democracy in East Central Europe”, Glob Policy 6, 2015, pp. 28-37.

10 B. Bugarič, op. cit., p. 232.

11 Ibid., p. 233; A. Matej, „Central Europe as a legal phenomenon”, European Perspectives Slovenia's Role in Visegrad Group 7, October 2015, no 2 (13), pp. 53-66, https://ssrn.com/ abstract $=2753782$ (access: 20.04.2018). 
culture within Central-Eastern European countries and "pure theory of law" (or "normativity") ${ }^{12}$ deriving from Kelsen. As strongly affected by ideological neutrality, abstractness and descriptive character ${ }^{13}$, it differs notably from Western legal systems (particularly Anglo-Saxon ones), where positivism is mitigated by approach more of a "integral conception of law" by Ronald Dworkin, pursuant to which law cannot be differed effectively from morality ${ }^{14}$. The assumptions of integral conception of law together with elements derived from the institutional theory of law ${ }^{15}$ indicate that the most significant factor for the purpose of the proper functioning of legal institutions is the human factor accepting and regularly internalizing norms of a whole legal system. Pursuant to this conception, it is an integrity of society (including morality and coherency) which shapes a legal reality — and not the opposite ${ }^{16}$. However, the legal systems of Central-Eastern European countries are historically characterized by prioritization (to a great extent), authoritarianism and lack of discursiveness, known even in mature Western democracies. The law in Central-Eastern Europe has not been becoming the law as a result of process of discussion and mutual convincing, but only because of that it has been implemented into the legal system in a valid and non-defect way. As Matej Abveli points out, this "Austro-Hungarian" concept of law has been best captured in "The Trial" by Franz Kafka ${ }^{17}$. Therefore, the idea of legalism known in Western systems has been distorted by legal normativity known in Central-Eastern European countries, together with communistic legalism ${ }^{18}$. After the fall of communism, the societies in Central-Eastern Europe have been faced with a difficult objective to build a new law and institutions basically from scratch - which has not met often a broad popular support, but instead it has been imposed from the top by local political elites (for example by the United States or the European Union).

Another reason for the current situation in Central-Eastern European countries is a significant impact of so-called "temporary constitutionalism" doctrine, an uncritical adoption of which prevented from undergoing a proper transformation ${ }^{19}$. This theory is rooted in the formerly popular Washington Consensus ${ }^{20}$ doctrine, which promoted a rapid infusion of free-market principles into the economy, budget savings, opening up to outside capital and removing barriers to free move-

12 A. Matej, op. cit., pp. 56-57.

13 H. Kelsen, Pure Theory of Law, Gloucester 1989.

14 R. Dworkin, Law's Empire, Harvard University Press 1986.

15 N. MacCormick, Institutions of Law: Law State and Practical Reason, Oxford 2007.

16 A. Matej, op. cit., pp. 56-57.

17 Ibid., p. 59.

18 Ibid., p. 60.

19 B. Bugarič, op. cit., p. 232.

20 J. Williamson, „What Washington Means by Policy Reform”, [in:] Latin American Readjustment: How Much Has Happened (John Williamson ed., 1989). 
ment thereof, and unrestrained privatization ${ }^{21}$. The Washington Consensus, promoted by the International Monetary Fund, the World Bank and US Treasury, was supposed to provide a remedy for "infected" economies of the postcommunist countries of Central-Eastern Europe (and a decade earlier - of Latin America). However, too neoliberal and monetarist tendencies appeared as a defect of this approach - and a goal thereof was, in general, to keep to a minimum a role of the country, mostly for the purposes of private ownership protection, safety of trade and law, and to grant enforceability of contracts deriving from new investments, with the aid of formerly established institutions resembling their Western counterparts (for example autonomous Central Bank, as well as independent judiciary). In other words - the process of reviving the economy and the framework for capitalist countries has hidden the other aspects. The problem of building a new civil society and effective democratic public institutions has been pushed further into the background ${ }^{22}$.

What is more, in many Central-Eastern European countries together with the fall of communism there appeared a sudden and uncritical reception of Western constitutional institutions and legal systems on a national level ${ }^{23}$. However, this process was conducted on the basis of a simplistic assumptions that the procedure of building democracy should be carried out in an express way, following a strictly determined manner, modelled after Western countries. In doing so, it was forgotten however that this process in European countries has been very intense, it required time and numerous legal experiments. That context has been totally lost under the transformation in Central-Eastern Europe. The "new-old" political elites, tempted by a perspective of benefits connected with EU accession, and, simultaneously, mindful of the requirements formally imposed in accession procedure, de facto just copied foreign solutions, pursuant to the theory, that application of a sole, universal strategy is possible to all the systems equally ${ }^{24}$. Instead of carefully cutting their coats according to their cloth, by experimenting with many different legal institutions, the elites have been directed by "institutional optimism" and unconditional belief in rightness of foreign democracies' solutions. Therefore, it indicates a kind of paradox of Central-Eastern European countries transformation: a construction of democratic state based on the rule of law, implemented uncritically from the West, has diluted the basics of those institutions before they could even take up their role. This problem is also connected with the phenomenon of "shallow institutionalization" of institutions characteristic of democratic state based on the rule of $\mathrm{law}^{25}$. A need of profound reform thereof

\footnotetext{
21 B. Bugarič, op. cit., p. 233.

22 Ibid., p. 234.

23 Ibid., p. 235.

24 Ibid., p. 239.

25 Ibid., p. 233.
} 
has become popular only within a short period of time connected with rigorous EU accession mechanism, however this process has been only a subtle "illusion" in most of Central-Eastern European countries. With reference to the "return to Europe" rhetoric, in reality completely apparent institutions have been established, a function (clearly propaganda) of which has been only to make impression of being modern and "European" ones.

As a reason of the last perturbations is mentioned also the distance of Central-Eastern Europe societies to mature and developed political systems of the West $^{26}$, even though the illusive reception of the latter appeared in those countries. They are characterized by underdevelopment of public institutions and signs of developed civil society, known in the Western countries. It is also connected with a low level of social engagement into politics, lack of trust in politicians and institutions of democratic state based on the rule of law. Moreover, the party system is characterized by high volatility and many fluctuations ${ }^{27}$. The parties themselves are connected with a high fragmentation and low level of their actual members, which following causes their exclusivity and lack of stable political opinions. Those frequent changes are treated in a very instrumental manner aimed strictly at always upcoming elections. Another tendency visible in many Central-Eastern European countries is personality cult - particular initiatives in politics are based around charismatic leader and are collapsed right after its political demise or resignation. As a result, some authors point out also a new phenomenon of so-called "legal constitutionalism" in Central-Eastern European countries, which is put in contraposition with classic model of "democratic" or "political" 28 constitutionalism. That fist one is characterized by a lack of profound social legitimacy, appearance of legal framework, and lack of internalization of real values of democratic state of politics within the society and its elites.

Finally, what is puzzling is an exceptional passivity and inertia of the European Union towards the crisis of constitutional values in Central-Eastern European countries, expressed in a lack of ability of EU institutions to stop the negative tendencies. Three main issues should be mentioned. Firstly, an acute weakness of legal instruments which are available to EU. However the member countries have undertaken to respect commitments deriving from treaties (art. 2 of TEU), as well as protect basic values such as democracy, pluralism and legalism, their protection mechanism included in the article 7 of TEU is characterized by its impracticability, due to high requirements in order to commence $\mathrm{it}^{29}$. It is also clear that it lacks of

26 M. Tomsic, ,Decline of elite consensus and destabilization of political space in east-central Europe", Corvinus Journal of Sociology and Social Policy 8, 2017, 3S, pp. 158-159.

27 M. Tomsic, op. cit., p. 159-160.

28 B. Bugarič, op. cit., p. 232-234.

29 R. Kelemen, „Europe's other democratic deficit: National authoritarianism in Europe's Democratic Union", Government and Opposition 52(2), 2017, p. 212. 
regular control and rule of law monitoring in particular EU countries, modelled after cooperation and control mechanism, applied during "around-accession" per$\operatorname{iod}^{30}$. Second, pursuant to opinions of some of the commentators, internal party politics within the EU itself has also a profound meaning. It is a result of the EU Parliament's tendencies to defend the parties constituting their parts, even if they are responsible for the crisis of democracy values within the state itself $f^{31}$. The progressively growing role of the EU Parliament, being a response to the postulates for the bigger EU democratization, leads to a phenomenon of tolerating anti-democratic parties by Union coalition, in exchange for valuable votes. Third, it is worth noting that Central-Eastern European countries' economies, while being the biggest beneficiaries of EU funds, they have also become largely dependent on payment thereof. Many different political connections are, therefore, in a favourable position - having already influence in disposing and share of funds, they increase their influences on a local level ${ }^{32}$ to the detriment of the opposition. On the other hand, there is no real legal or political possibility to support, even financially, the opposition in the relevant country, because it would cause an accusation of intruding in the internal affairs of the sovereign country. Similar actions would even constitute a satisfying material for propaganda of local political set-up. On the basis of the previous reflections J. Müller posed abstract but not so hypothetical question - whether a dictatorship can function within EU ${ }^{33}$

\section{Conclusion}

It turns out that despite illusive similarity, the Western democracies remarkably better deal with attempts to undermine the pluralistic institutions of a state based on the rule of law - mainly due to their deep professionalism and independence, as well as because of their tradition is stronger rooted in collective political identity of society ${ }^{34}$.

The analysis of complex causes for the current political arena of the Central-Eastern European countries indicates that an actual anti-democratic tendency was highly possible to presume and is rationally attached to many structural causes, which have been ignored for years by the Western partners.

30 R. Kelemen, op. cit., p. 212.

31 R. Kelemen, op. cit., p. 218; U. Sedelmeier, „Anchoring democracy from above? The European Union and democratic backsliding in Hungary and Romania after accession", Journal of Common Market Studies 52(1), 2014, p. 119.

32 R. Kelemen, op. cit., p. 216; C. Gervasoni, „A rentier theory of subnational regimes”, World Politics 62, 2010, issue 2, pp. 302-340.

33 J. Müller, „Safeguarding democracy inside the EU Brussels and the future of liberal order”, Transatlantic Academy Paper Series February 2013, p. 1.

34 B. Bugarič, op. cit., p. 232-234. 
In order to cure the situation of constitutional identity crisis in Central-Eastern European, many interesting proposals for remedies are coming forward as made by particular authors. However their detailed description far surpasses the assumed boundaries of this review, the most interesting of them are, amongst others:

- equipping the European Union with effective legal means in order to mitigate the described phenomenon (for example by an extension of art. 7 of TUE by financial sanctions or possibility of withdrawal the country from the EU structures ${ }^{35}$ );

- creating permanent mechanism, analogous to CVM, of examination of legality in all member countries with the character of apolitical "check list", however taking into consideration the specific nature of the relevant legal system; ${ }^{36}$

- intensifying regional cooperation by the Visehrad Group in order to promote original, locally examined and pro-democratic system solutions ${ }^{37}$.

Notwithstanding the foregoing, without doubt the process of democratization should be reformed (from elitist and imposed from the top to the bottom-up one), in connection with placing particular focus on building a broad support for the constitutional democracy, civil society and institutions of democratic state based on the rule of law. In order to gain full confidence and social support, the system transformation should be performed with the aid of means more participatory than exclusively law and illusive public institutions. We can only hope that the recent anti-democratic trends in the Central-Eastern Europe countries will inspire national and European elites to change the current perspective. Discontinuation of constitutional identity crisis together with creation of stable and pluralistic legal system require not only the relevant legal instruments system, but, first of all, a broad consensus and support for democratic values from all the society of Central-Eastern Europe countries.

\section{References}

Bugarič B., “A crisis of constitutional democracy in post-Communist Europe: 'Lands in-between' democracy and authoritarianism, International Journal of Constitutional Law 13, January 2015, issue 1.

Dworkin R., Law's Empire, Harvard University Press 1986.

Freedom House, Nations in Transit 2018: Confronting Illiberalism (2018), https:// freedomhouse. org/report/nations-transit/nations-transit-2018.

Ganev V.I., "Post-accession hooliganism: Democratic governance in Bulgaria and Romania after 2007”, E. Eur. Pol. \& Societies \& Cultures 27, 2013, issue 1.

Gervasoni C., "A rentier theory of subnational regimes, World Politics 62, 2010, issue 2.

Greskovits B., "The hollowing and backsliding of democracy in East Central Europe", Glob Policy 6, 2015.

\footnotetext{
35 J. Müller, Safeguarding Democracy..., p. 23.

36 Ibid., pp. 24-25.

37 A. Matej, op. cit., pp. 62-63.
} 
Guasti P., Dobovšek B., Ažman B., "Deficiencies in the Rule of Law in Slovenia in the Context of Central and Eastern Europe", Varstvoslovje. J. Crim. Justice \& Security 14, 2013, issue 2.

Kelemen R., "Europe's other democratic deficit: National authoritarianism in Europe's Democratic Union", Government and Opposition 52(2), 2017.

Kelsen H., Pure Theory of Law, Gloucester 1989.

MacCormick N., Institutions of Law: Law State and Practical Reason, Oxford 2007.

Matej A., "Central Europe as a legal phenomenon", European Perspectives - Slovenia's Role in Visegrad Group 7, October 2015, no. 2(13), pp. 53-66, https://ssrn.com/abstract=2753782.

Müller J., "Defending democracy within the EU", J. Democracy 24, 2013, issue 2, pp. 138-140, https:// freedomhouse.org/report/nations-transit/2018/hungary.

Müller J., "Safeguarding Democracy inside the EU Brussels and the Future of Liberal Order", Transatlantic Academy Paper Series, February 2013.

Rupnik J., Zielonka J., "Introduction: The state of democracy 20 years on: Domestic and external factors", E. Eur. Pol. \& Societies \& Cultures 27, 2013, issue 1.

Sedelmeier U., "Anchoring democracy from above? The European Union and democratic backsliding in Hungary and Romania after accession", Journal of Common Market Studies 52, 2014, issue 1.

Tomsic M., "Decline of elite consensus and destabilization of political space in East-Central Europe", Corvinus Journal of Sociology and Social Policy 8, 2017.

Williamson J., What Washington Means by Policy Reform, [in:] Latin American Readjustment: How Much Has Happened" (John Williamson ed., 1989).

\section{Latest remarks on the democracy and rule of law in CEE countries}

\section{Summary}

Pursuant to the actual report Nations in Transit 2018, published by Freedom House organization, the year of 2018 led to the biggest decrease in a point-measured quality of democracy and the rule of law in CEE countries throughout the history of the rating, lasting 23 years. In the last decade those countries distanced themselves from value system well-known in the so-called "Old Europe", which is a presentation of acts assigned more to the "buffer zone" between the West and the East of Europe. Therefore, despite the illusive ideological solidarity, common values and increasing harmonization of law within the European Community, a contrast between the image and the reality has become visible. It turned out that apparently democratically mature and following the principle of legalism countries (in its European scale) are, in reality, functioning in the shadows of informal networks, political systems and local correlations. There are many potential reasons behind this state of affairs. Firstly, many commentators notice that due to traumatic historic events, all the region is characterized by a weak rule of law tradition regarding issues such as human rights, protection of minorities rights and, in general, a connection between law and morality. Another reason for the current situation in Central-Eastern European countries is a significant impact of so-called "temporary constitutionalism" doctrine, uncritical adoption of which prevented from undergoing a proper transformation. What is more, in many Central-Eastern European countries together with the fall of communism there appeared a sudden and uncritical reception of Western constitutional institutions and legal systems on a national level. However, this process was conducted on the basis of simplistic assumptions that the procedure of building democracy should be carried out in an express way, following a strictly determined manner, modelled after Western countries. In doing so, it was forgotten however that this process in European countries has been very intense, required time and numerous legal experiments. That context has been totally lost under the transformation in Central-Eastern Europe. As a reason of the last perturbations is also 
mentioned the distance of Central-Eastern Europe societies to mature and developed political systems of the West, even though the illusive reception of the latter appeared in those countries. They are characterized by underdevelopment of public institutions and signs of developed civil society, known in the Western countries.

Finally, what is puzzling is an exceptional passivity and inertia of the European Union towards the crisis of constitutional values in Central-Eastern European countries, expressed in a lack of ability of EU institutions to stop the negative tendencies. It turns out that despite the illusive similarity, the Western democracies remarkably better deal with attempts to undermine the pluralistic institutions of a state based on the rule of law - mainly due to their deep professionalism and independence, as well as because of their tradition is stronger rooted in the collective political identity of society. The analysis of complex causes for the current political arena of the CentralEastern European countries indicates that an actual anti-democratic tendency was highly possible to presume and is rationally attached to many structural causes, which have been ignored for years by the Western partners. Notwithstanding the foregoing, without a doubt the process of democratization should be reformed (from elitist and imposed from the top to the bottom-up one), in connection with placing particular focus on building broad support for the constitutional democracy, civil society and institutions of a democratic state based on the rule of law. In order to gain full confidence and social support, the system transformation should be performed with the aid of means more participatory than exclusively law and illusive public institutions. 